This article was downloaded by: [New York University]

On: 01 May 2015, At: 19:07

Publisher: Routledge

Informa Ltd Registered in England and Wales Registered Number: 1072954

Registered office: Mortimer House, 37-41 Mortimer Street, London W1T

3J H, UK

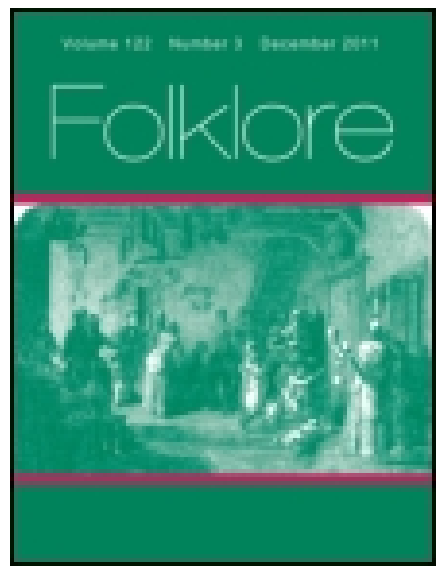

\title{
Folklore
}

Publication details, including instructions for authors and subscription information:

http:// www. tandfonline.com/loi/ rfol20

\section{Address to the Folk-Lore Society}

Andrew Lang

Published online: 14 Feb 2012.

To cite this article: Andrew Lang (1890) Address to the Folk-Lore Society, Folklore, 1:1, 4-16, DOI: 10.1080/ 0015587X.1890.9719994

To link to this article: http:// dx. doi. org/ 10.1080/0015587X.1890.9719994

\section{PLEASE SCROLL DOWN FOR ARTICLE}

Taylor \& Francis makes every effort to ensure the accuracy of all the information (the "Content") contained in the publications on our platform. However, Taylor \& Francis, our agents, and our licensors make no representations or warranties whatsoever as to the accuracy, completeness, or suitability for any purpose of the Content. Any opinions and views expressed in this publication are the opinions and views of the authors, and are not the views of or endorsed by Taylor \& Francis. The accuracy of the Content should not be relied upon and should be independently verified with primary sources of information. Taylor and Francis shall not be liable for any losses, actions, claims, proceedings, demands, costs, expenses, damages, and other liabilities whatsoever or howsoever caused arising directly or indirectly in connection with, in relation to or arising out of the use of the Content.

This article may be used for research, teaching, and private study purposes. Any substantial or systematic reproduction, redistribution, reselling, loan, sub-licensing, systematic supply, or distribution in any form to anyone is 
expressly forbidden. Terms $\&$ Conditions of access and use can be found at http://www.tandfonline.com/page/terms-and-conditions 


\title{
ADDRESS TO THE FOLK-LORE
}

SOCIETY.

\author{
SESSION I889-90.
}

\begin{abstract}
T ADIES AND GENTLEMEN,-Before making the usual remarks on the position and prospects of Folklore, I ought, I think, to read you a letter just received from the Secretary of the French Society akin to our own, M. Paul Sébillot.
\end{abstract}

"Ministere des Travaux Publics, Cabinet du Ministre.

"Paris, lo 19 Nov. 1889.

"Monsieur la Président,-Au nom de la Societé des Traditions populaires, je viens adresser a Folk-lore Society, a l'occasion de son meeting annuel, tous nos voux pour la continuation de sa prospérite.

"Votre Sociéte, dont beaucoup de membres font en même temps partie de la notre, apprendra sans doute avec plaisir que le nombre de nos Societtaires dépasse trois cents, et qu'ainsi son existence est assuré. L'hiver prochain, nous allons pouvoir tenir des Assemblées périodiques, dans lesquelles seront discutés les problemes qui interessent le Folllore, et a cóté de notre Revue, et sans en diminuer l'importance, nous allons fonder la Bibliotheque de Ma Mère l'Oye.

"Dans l'avant-dernier numero de la Rerue, vous avez pu voir qu'a notre tour nous abordons la 'tabulation' des Contes et des Légendes. La Revue des Traditions populaires est ouverte d' ceux des mẹmbres de Folk-lore Society qui désireraient discuter cette importante question. A la fin du Congres des Traditions populaires tenu a Paris, les deux voux suivants ont été adoptés, sur la proposition de M. Henri Cordier :-

" ' $3^{*}$. Adopter d'une façon gennérale la classification de Folk-lore Society, en donnant moins d'importance au sommaire et en subdivisant Cindex alphabetique des incidents en : personnages, animaux, lieux, incidents des objets, etc; au point de vue pratique rédiger les tables par fiches en prenant, par exemple, pour modele la Bibliotheca belgica, de Van der Hagen, afin que des échanges puissent etre faits entre les differentes societes folk-loriques.

" ' $2^{\circ}$. Le Congrès des Traditions populaires, réuni pour la première 
fois à Paris, se reunira comme le Congrès des Orientalistes d'une façon périodique; la prochaine session se tiendra à Londres dans deux ans, et M. Ch. T. Leland, president de Gypsy-lore Society, sera charge de l'organiser.'

"J'aurai aureste l'honneur de transmetter a Foll-lore Society l'analyse sommaire du Congrès qui est publié par les soins de l'Administration, et les Memoires in extenso qui serónt imprimés a part.

"Veuillez agréer, Monsieur le Président, l'assurance de mes sentiments les plus distingués

"PAUt Stábirot,

"Secretaire gentral de la Socitet des Traditions populaires, Secrttaire gentral du Congres."

You will authorise me, I trust, to express to Monsieur Sébillot our sense of his courteous communication, and our hope that the French Society may go on "from strength to strength advancing". Though she came rather late into the field of scientific folk-lore, it is to France that we owe our most familiar and dearest fairy-tales, those of Perrault and Madame d'Aulnay. If the French collected their volkslieder and their märchen later than did Germany, Denmark, and England, at least they collected them with assiduity and success, and have criticised them with learning and acuteness. It is not needful to do more than mention $M$. Sébillot himself, M. Cosquin, my own esteemed adversary in theory, M. Henri Gaidoz, to whose energy and erudition our science is such a debtor, M. Carnoy, M. Loys Brueyre, M. Eugene Rolland, and M. Gaston Paris, whose learning is so vast and so genial, with all the many living French authors who, not only at home but in Africa and Asia, widen the boundaries of our knowledge.

M. Sébillot speaks particularly of folk-tales, and their classification. From the Journal of the Society, and its reports, you know how that labour of the Danaids is speeding. For one, I look almost in despair at the vast mass of material, at the myriad tales told in every language known of mortals. "There is a deep, and who shall drain it?" says Sophocles; and who, indeed, shall drain and dredge what the Hindoos call the Ocean of the Stream of Stories? 
Who shall classify all its very queer fish, and who shall decide the course of their evolution and differentiation? I would not be discouraging to labourers in this field, and yet, when I look at the tables and analyses, it is rather despair than hope that animates me. Among these innumerable forms and shapes of fancy I seem to see that the elements are comparatively few, that the myriads of forms are the result of a few elements in infinite combinations. Is it impossible to exhaust these elements ? I occasionally dream, most of us who dabble in the matter do, of some new analysis, some swift and royal road to truth.

It appears that we do not yet know how far to discern between recently borrowed stories, when we meet them among alien peoples, Red, Black, or Yellow, and stories which are older than the recent visits from Europeans. How are we ever to get over this initial difficulty? Our only certainties we win, when a nation has a literature The nursery tales in Egyptian MSS. are, at all events, not of later date in Egypt than the age of those MSS. themselvcs, More we cannot say. We cannot maintain that they came from India, of which we know nothing at the time of the second Rameses, nor that they were indigenous to Egyptian soil, nor that they floated, like the golden and fragrant hair of the wife of Bitiou, down the Nile from Central Africa. We merely note that, even fifteen hundred years before our era, the elements of tales. current in our nurseries had already been interwoven with the official mythology and the popular religion of Egypt. Now we may affirm that imported tales would not instantly and hastily be blended with the stories of native and local gods. Beyond that, all.is conjecture. If we could read the MSS. of the old Aztecs, and if in them we found nursery tales like ours, we could then be sure that they were not derived from the Spanish conquerors nor from later European visitors. But we cannot read the Aztec MSS. The nearest we get to indubitably old American madrchen is the scanty collection of Huarochiri tales, printed by the Hakluyt Society. In 
these the elements of familiar European stories are interwoven (as in Egypt) with the legends of native and local gods, heroes, and sacred animals. To some of us this will be proof that they had existed in Southern America before Pizarro came. Others may sceptically allege, either that the Huarochiri borrowed their myths from the conquerors and inserted them in their native divine legends, or that the Spanish collector, like the Ettrick Shepherd's grandmother, was "aiblins an awfu' leear". My own sympathies are not with the sceptics.

Cases like this are very rare: the oldest voyagers seldom thought of collecting matrchen; it is quite by chance that we learn from Herodotus how the Scythians had the tale of the fortunate youngest son. Nor does that help us much; people will say that the Scythians borrowed it from India, and though they cannot prove, we cannot disprove, the statement. We seem on safer ground with the Zulus. They have only been in contact with Europeans for little over a century, and they have seen more of our bayonets than of our story-tellers. Whence, then, their wealth of märchen analogous to our own, but most closely intertwined with their peculiar national usages? Could the borrowing and the acclimatising have been accomplished since the first English crew landed in Natal? For my own part I think not: I think, if the elements of the stories were borrowed, they drifted south from the great lakes, in the course of commerce and national wanderings. There is no certainty, but an experiment might be tried. A missionary might tell his black flock tales out of Grimm, and, by careful watching, might learn how rapidly and to what extent they are modified into conformity with native usage. But here would be all the difference between intentional instruction, and the chance sowing of the seeds of story. There is also hope wherever we reach virgin soil. The natives of New Guinea can have learned, it might seem, but little of European märchen, yet their legends, of which Mr. Romilly has collected a few, are analogous to our own, 
though not very closely analogous. These considerations lead me to a suggestion which is not intended to supcrsede, but to accompany, the regular process of tabulation. That process, as we practise it, seems to me to do little but offer us a series of summaries. We have the bones of the tale, the skeleton-and a very dry skeleton it is-that is all. We might as well compare the stories with the life and blood in them. No harm could be done if some student would take two sets of stories-say, those of Dr. Callaway from the Zulus, and those of Asbiomsen and Möe, from the Norse. He might analyse each book apart, thus :

\section{Supernatural Incidents. \\ Traits of Manners. \\ Incidents not supernatural. \\ Characters-Supernatural.}

Animal.
Dividing the latter into $\begin{aligned} & \text { Names of Kindred. } \\ & \text { Of Trades and Occupations. } \\ & \text { Of Ranles and Offices. } \\ & \text { Personal Names. }\end{aligned}$

All this is not free from cross divisions; far from it. But when the typical tales of Scandinavians, Swahilis, Zulus, Hindoos, Samoyeds, Finns, Eskimo, Celts, Samoans, Maoris, had been analysed thus, perhaps we should have a general idea of what is common to humanity in their narratives, and what is peculiar to different peoples and tribes. If I may guess, I think the universal elements would be far greater than the isolated features. And, though many will disagree with me, I think the barbaric would be out of all proportion to the civilised factors in the stories. Each analyser would, to the best of his ability, explain the chances and processes of borrowing, from European or native neighbours of higher or lower civilisation than the tellers of the tales. For example, if we find the story of Rhampsinitus and the Thief among modern Egyptians, we should have to decide, Is it traditional there, or can it 


\section{Address to the Folk-Lore Society.}

be shown to be derived from modern travellers acquainted with Herodotus? Turning from this to a kindred topic, it would be pleasant to discuss Mr. Clodd's theory of Rumpelstiltzkin. Wherever we find a form of this tale, the result hangs on the discovery of the name of a supernatural being. Mr. Clodd, if I understand his article in our Journal, explains this as a survival of the world-wide belief that to know a man's name gives you power over the man-a belief shown in the dislike of savages to reveal their own or their neighbours' names. Rome, as we all know, had a secret name, for similar reasons. To myself, the story of Whuppity Stourie or Rumpelstiltzkin seems not necessarily to have so archaic an origin. The elf or fairy simply relies on possessing a name so unusual and odd that nobody is likely to guess it. It answers to the anecdote of Mr. R. L. Stevenson and the curious American, who met him on the plains, found a mystery in him, and did everything to know what his name was. Mr. Stevenson mystified him till he met him in San Francisco, and then disappointed him horribly by saying that Stevenson, plain Stevenson, was his name. There is no more than a jest of that sort, to my mind, in Rumpelstiltzkin. The heroine gets no magical hold over the elf by knowing the name, no hold at all beyond what the elf has himself given by way of a wager on a kind of riddle. Wagering on divinettes or riddles is itself a savage amusement, and we have many examples in the Scotch ballads. Mr. Clodd would have convinced me, if the power secured over the elf was magical, if it was not, in all cases, a wager or bet, the elf being confident 'in the possession of a very odd name. That of Whuppity Stourie, perhaps, is derived from the stour, or flying dust, in which Scotch and other fairies are believed to fly about.

As to the origin and diffusion of popular tales, it does not seem that we learn much more, with all our labour. Other members of the Society no doubt understand better than I do the theories of a White Archaian Race, which, it 
seems, in some very distant past, invented the essentials of civilisation, myths, art, and everything, and handed them on to races who were neither Archaian nor White. How we know the colour of this important people, and wherefore they are called Archaian, where they came from, whither they went, and what, in the words of the son of Father William, "made them so awfully clever", I confess that I do not understand. This, of itself, proves nothing ; we are as ignorant of whence the Egyptians came, and of the beginning, which must have preceded the art of the ancient empire. The spade may yet let air and light into this dark place, or geographers in pathless downs of unexplored Central Africa may find the Archaian whites all at home, or may hit on the ruins of their primeval civilisation. But, so far, the Archaian race seem to me to dwell in Laputa, or $\mathrm{Zu}$ Vendis, or El Dorado, rather than in any more substantial city. On this point, too, we may receive information.

Another important example of recent folk-lore study is Mr. Gomme's essay on "Totemism in Britain". I need not explain to the Society what totemism is-the belief that certain kindreds descend from animals, plants, and other natural objects and phenomena, the naming of the kindred after these objects, and a certain sacredness which, in each kin, is ascribed to the animal, plant, or what not. Many years ago, I mentioned the existence in Jld England of stocks called by the names of plants and unimals. That of itself at least raises a presumption, and suggests research. A man may be called Fox or Hare, a stock may be called Wallings, Derings, and so forth, yet their ancestors may never have traced descent to whale or deer, hare or fox. I have since, I think in Myth, Ritual, and Religion, given a few traditions, mainly Celtic, of lescent from seals, wolves, and so forth, as, in the case of Conaire, from a bird, coupled, in Conaire's case, with the :otemistic prohibition to eat birds. Now, when you get confessed belief in animal descent, a name declaring that 
descent, and sacredness attached to the animal or other fancied ancestor, you have totemism scarcely to be argued against. Mr. Gomme has found examples in Clan Connolly, derived from Coneely, a seal, the clan holding it unlucky to kill seals, and maintaining that some of their ancestors were changed into seals in ancient times. This is good enough for me; here, I think, we have totemism. It is almost beyond the calculus of chances that such a foolish faith should have arisen accidentally, separately, unconnected with the causes, whatever they may be, which produce totemism among red men, black men, yellow men. But I think we must be extremely cautious in regarding superstitions at large about animals as vestiges of totemism. The whole superstition of metamorphosis may exist apart from totemism. People may believe that witches turn into hares, and souls into spiders or butterflies ; they may decline to kill spiders like the Bruces, or to mention salmon ; they may wear the salmon as a badge, like the Campbells; they may dress up in the skins of beasts in sacred dances; they may assume names from animals, and object to killing certain animals, and yet totemism may have nothing to do with any of these customs. They are all customs or beliefs which totemists do practise, yet the animal name may be a mere nickname; the wearing of animal skins may have a magical purpose, the badge may be a mere amulet or fancy, the metamorphosis may be not totemistic, but a myth derived from a name, a pun, or from a poetic guess ; there may be special causes, in fact, and totemism may have nothing to say in the matter. Is it not plain that a white night-moth may be fancifully or superstitiously called a "soul" from its soft, ghost-like flight in the darkness, though no tribe ever claimed descent from the moth? The birds into which the Huron witch and her son were changed, in Lafitau, were not said to be the totems of the family, any more than a lion, or an elephant, or a mouse was the totem of the Ogre in Puss in Boots. In short, I cannot, even provisionally, call cats, hares, magpies, butterflies, 
sparrows, swans, wrens, ravens, otters, "totem objects" in England, with Mr. Gomme. They may, or may not, have been totems, but the superstitions about most of them may have a dozen different and non-totemistic origins. Where salmon are not named by fishers, as usual in Scotland, I fancy the superstitious fear is that the fish may hear his name, and make off. The minister, also, may not be named at salmon fishing; will Mr. Gomme say that the worthy clergyman has been a totem? You may object to cut down a tree, not because your ancestors once believed in descent from it, but because it is the home of a bogie or fairy, or what not, which is unconnected with totemism. A grove may be sacred like that of Lyceian Zeus, for the same sacred reason. People have abstained from eating cows, not because they were totems, but because they were so valuable in other ways. Again, totemists are said to keep pet specimens of their totems, like the sacred mice in the temple of Sminthian Apollo, but who would argue that boys keep guinea-pigs, rabbits, toads, ravens, and so forth, as a survival of totemism? Even where the animals are sacred, totemism may have nothing to do with it. It is a question of proof in each case. The swallow is esteemed, as in the old Greek popular song, because he "brings the spring", not because he is a totem. Ceyx and Halcyone were metamorphosed in a poetical myth, totemism has no part here. Pregnant women, "if frightened by a hare", are said to have children with hare lips. What on earth has this to do with disrespect to the totem ? A woman frightened by a black man may have a black baby for all that I know, but the black man is not a totem. Mr. Gomme includes the peacock, because the screams of a peacock are thought to forebode death. Is the peacock a native bird, or was this superstition brought from his native home? Is a death-watch a totem?. If a trout catch worms, is that because a trout was once a totem, or because trout eat worms and are their natural enemies?

It will be observed that I speak as Advocatus diaboli. 
Nobody is more apt to believe in totems than myself, and perhaps I am more inclined than Mr. Gomme to think that the Aryans went through a stage of society and culture so very common as this totemism was. Why should the Aryans have been better than other people? The myths of Greece and the ritual of Greece are full of what I regard as very probably totemistic survivals. People may say these were borrowed. They cannot prove it ; and, if it is true, so much the worse for the Greeks. But, at the cost of seeming to claim to be the only true believer in totemism, I must protest that I think we cannot be too careful. Mr. Gomme has found some two or three cases of totemism in these countries, mainly in an isle notorious for its verdure and its wrongs, which seem beyond doubt. Others he has found where there is a very strong presumption of totemism. The vast mass of his examples may spring from totemism, but other explanations, and singular causes are admissible. To me it seems premature to "colligate" all those scattered superstitions by the totemistic hypothesis. It may give the enemy, who believes in the omnipresence of solar myths turning on a Disease of Language, it may give him occasion to shoot out the tongue. This does not prevent Mr. Gomme's essay from being most interesting, and, in a few cases, I think conclusive. But it is a long way from presumption to proof. In short, it is true that totemism if once prevalent in Britain would have left behind it just such relics as Mr. Gomme has carefully collected. But the prevalence of these relics does not demonstrate the previous existence of totemism.

Among Mr. Gomme's possible relics is the custom of wearing beasts' skins in certain old merry-makings. These are curious; but to "hang a calf-skin on thy recreant limbs" may be practised without totemistic intention. I think Catlin mentions dances of men thus draped, for the purpose of securing luck in the chase. As to names from beasts, even critical totemists derive their personal, as we should say, their Christian names from beasts without any 
totemistic meaning. Chingachgook, the Mohican, was not a serpent by family or totemism. We were all at school with boys called Pussy, Piggy, Monkey, and so forth. Thus, on the whoje, we feel driven back to the opinion that, though our folk-lore may, and probably does, hold traces of totemism, the evidence is by no means good enough to contvince our opponent, except in two or three cases, and those Irish

It wrould be pleasant, were it possible, to review all the fresh contributions to the year's folk-lore But for that purpose a man would need much leisure, and a knowledge of all European languages, including Finnish. 1 shall offer a few remarks on ballads. Professor Child of Harvard has put forth the sixth of his eight volumes, and we cannot too kindly congratulate America on his most valuable and really exhaustive work. On one point Mr. Child has not yet convinced me. We all know the ballad of Marie Hamilton, executed for killing her own child, by Darnley, at the Court of Mary Stuart Now Kiskpatrick Sharpe fancied that this ballad was founded on the death of a Miss Hamilton, a maid-orhonour at the Court of Peter the Great Mr. Child adopts this opinion, "howerer surprising it may be, or seem, that, as late as the eighteenth century, the popular genius, beiped by nothing but a name, should have been able so to fashion and colour an episode in the history of a distant country as to make it fit very plausibly into the times of Mary Stuart" Now it is true that none of the Queen's Maries died for an intrigue with Damley. But a French woman of the Queen's chamber did suffer for child-murder, and Knox expressly states that there were ballads about the Maries and the rest of the dancers of the court". To me it seerns more plausible that, given an actual scandal, and given ballads about the Maries, the ballads finally adapted the scandal, than that, in the eighteenth century, so many ballads were made about Niss Ilamilton in Russia, and were fitted into the time of 
Mary Stuart So late a ballad would have been more historical and less poetical. The lady was executed in Russia in 1719. Burns quotes a verse of the ballad in 1790 . Could eighteen very diverse variants have been made of a ballad on a contemporary event, in less than a century? Perhaps no ballad has so many variants; one of them even enables the lover to save the lady's life. I cannot believe that this mass of myths is the growth of part of the last century, nor sprung from an event in a distant though contemporary court. But Mr. Child seems to think this the only tenable opinion, and it is certainly curious that the lady seems to be dying across seas far from home. But her parents might have been in France, or might have lived near a Scotch seaport, hence her address to the mariners, which, itself, has a parallel in a Romaic ballad.

The problems of Folk-Lore are infinite. We have only guessed at a few of them, and, perhaps, have only demonstrated that we are likely to go on guessing. But that is a very old form of the sport; and, if the Philistines mock us, it may be by an inherited distaste, for Samson, when it came to guessing riddles, had the better of the Philistines.

ANDREW LANG.

\section{Discussion.}

Mr. NUTr drew the altention of the meeting to Jeanroy's theory of the origins of the ballad literature of modern Western Europe as derived from medizeral French lyric poetry, which has now disappeared, but the existence of which was postulated by the author in order to account for foll-poesy.

Mr. GoMmr thought it was a good thing once a year, in taking stock of our progress, to hear objections to our methods, instead of being content with compliments. But objections raised, even by the great authority of our President, need not off-hand be considered as objections proved. He (Mr. Gomme) was concerned chiefly with two subjects, one a personal one, the other a general one. The President had done him the honour of specially criticising his paper on "Totemism in Britain." The President objected to some of his 
evidence, because certain superstitions and customs might be referred to some other origin than that of totemism. Mr. Gomme's argument throughout the paper was that totemism, having been suggested by the evidence of place-names and some other evidence-if it existed among the tribes of Britain .like it existed elsewhere, it must have imprinted itself on folk-lore. Then, with this hypothesis be had classified the superstitions of animals and plants current in Britain under heads derived from savage totemism, and be had found that they fitted the classification so completely, each section overlapping to such an extent as to justify such a classification being established as a working hypothesis only for future labonrers. With reference to the more general question of criticism by the President, the Society's method of tabulation, Mr. Gomme wished to enter a strong protest against any plea for change of action. Of course, no one would use for scientific purposes the abstract of tales only, but they would use the abstracts as a guide to the tales themselves. Mr. Gomme thought the President's suggestion to compare whole collections of one savage or barbaric people with whole collections such as Grimm's a most valuable one, but still the tabulations would assist in such work as this. The tabulation of folk-tales was not a process like Mr. Spencer's tabulation of sociological phenomena, because no choice was left to the tabulator of folk-tales; he had simply to set down all and everything. We might possibly improve the form, and certainly the index of incidents was one branch of the tabulation which needed close attention, great care, and considerable improvement of method by the tabulators. But this could be accomplished, and still the present method might stand. The present method had been decided upon by a committee of eminent specialists in foll-tales, and he thought, until some considerable progress had been made, it was too early to speak of the scantiness of results. There were many workers, and they were working hard. He hoped that when some of this work was garnered, the President would admit that the Society's plan was valuable. It would be enhanced ten-fold if other countries could be got to adopt the same or a slightly modified plan, and he thought some of M. Ploix's suggestions in a recent issue of Revue des Traditions might be acted upon.

Prof. RHYs brought forward some examples of anecdotes about animals from Celtic saga which, he thought, might plausibly be traced to totemism.

Rev. A. Lőwy remarked that a knowledge of a person's name played a great part in many Oriental legends. 